\title{
The Relationship between Blue-Girdled Angelfish (Pomacanthus Navarchus) Exploitation and Availability for a Sustainable Fishery in South Sulawesi
}

\author{
Mauli Kasmi, Asriany, Karma \\ Agribusiness Department of Fisheries, Agriculture Polytechnic State Pangkep \\ South Sulawesi
}

Received: October 8, 2016 Accepted: December 17, 2016 Published: December 27, 2016

doi:10.5296/jas.v5i1.10511

URL: http://dx.doi.org/10.5296/jas.v5i1.10511

\begin{abstract}
Blue-girdled angelfish, Pomacanthus navarchus is marine, expensive ornamental fish and is gaining popularity to be traded globally from which the social welfare increases. The study aims to (1) analyze exploitation status of fish regarding fish stock sustainability in South Sulawesi water, and (2) find out fish availability and demand in terms of exploitation level. Making the estimation of exploitation level, it applies optimum effort (Eopt) using FOX model; and making the prediction of fish demand and supply, it applies least square method. The findings indicate the exploitation status of fish in South Sulawesi water has been, in general, far above the total allowable catch (TAC), while the backward bending curve of fish availability indicates decreasing supply yet increasing fish price.
\end{abstract}

Keywords: Exploitation, supply, sustainability, business, ornamental fish, blue-girdled angelfish

\section{Introduction}

Blue-girdled angelfish (Pomacanthus navarchus) is the most high-priced ornamental fish in trade sector because of its shape and eye-catching color. It is gaining popularity among saltwater aquarium collectors and is one of export commodity in fishing industry.

Blue-girdled angelfish from family Pomancanthidae (Angelfish), has an attractive shape, every species has their own special characteristics that makes this ornamental fish, in the aquarium trade, priced high compared to other fish families. All angelfish species stay among coral reef in tropical water, live solitary or in pairs that can be found between 1 to 50 m deep (Kasmi et al., 2011).

Blue-girdled angelfish grows to a size of $40 \mathrm{~cm}$ in length taking on black coloration on the 


\section{Ml Macrothink}

pectoral fin, and yellow coloration on the dorsal and caudal fin. It has soft dorsal fin with black and yellow stripes along its body, rounded or lunate tail fins with blue edge. It has white, blue edge ventral and anal fins. The dorsal fins have 13-14 strong fins and 16-18 soft fins, and the anal fins consist of 3 strong fins and 16-18 soft fins. (The Agency for Marine and Fisheries Research, 2006)(Figure 1).

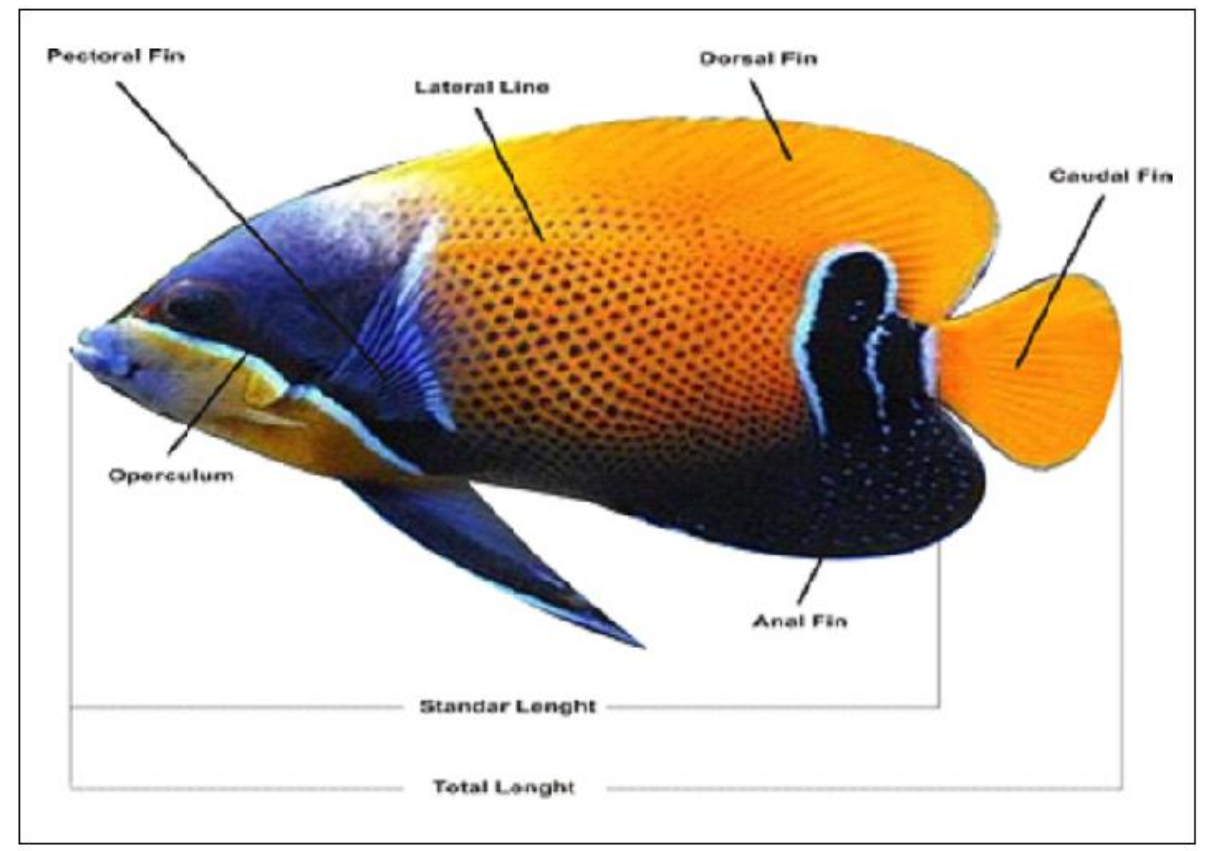

Figure 1. Morphology of Angelfish (Pomachantus navarchus)

South Sulawesi water is fairly potential as the fishing area of blue-girdled angelfish (Pomacanthus navarchus). It is observable based on the fisherman numbers intensively catching this species to meet a high demand, especially from the developing and developed countries (Indra, 2007, Kasmi and Sulkifli, 2013). If it remains uncontrolled, it evokes concern that the fish population will drop fast. This fish production depends on the wild-caught behavior because the breeding effort does not work yet.

In context of sustainable fishery resource management, it requires information on recent ornamental fish exploitation status including production level, stock availability, and reproductive system. Fishery resource management is an effort made to escalate fishery resource exploitation by conserving its sustainability. In general, fishery resource management is not organism-based management, but it focuses on an effort to manage fishing activity and to conserve the environment (FAO, 1995; Charles, 2001).

The study aims to find out the exploitation status of fish regarding fish stock sustainability in South Sulawesi water, and to find out fish availability and demand in terms of the exploitation level.

Research findings, hopefully, will be useful as scientific information outlining exploitation status, market supply and demand of the angelfish in South Sulawesi water. 


\section{Research Methodology}

The study is organized from March to May, 2015 in export-oriented ornamental fish small and medium-sized enterprise (SME) across South Sulawesi Province.

\subsection{Angelfish Exploitation Status}

Observation of the angelfish exploitation status uses 2 data: Primary Data which is collected directly from the field by observation and interview with respondent, such as business unit; and Secondary Data which is collected from office or company as well from ornamental fish-oriented business units, they are Asosiasi Koral, Kerang, dan Ikan Hias Indonesia (AKKII/the Indonesia Coral, Shell and Ornamental Fish Association) and Asosiasi Koral dan Ikan Hias Sulawesi (AKIS/the Sulawesi Coral and Ornamental Fish Association) to complete the primary data, such as the data of production and fish price during the last ten years.

\subsection{Angelfish Supply and Demand as Export Commodity}

Research methodologies used in this study are descriptive and explanatory method. Types of data used in the study based on the dimensions of time are time series data and cross section data collected from ornamental fish exporter. Time-series data, including fish production, price and size which are collected from business unit and ornamental fish association during the last ten years, are used to analyze trend prediction for export-oriented fish.

\subsection{Data Analysis}

\subsubsection{Exploitation Status}

Catch per unit effort $(C / f)$ constitutes relative density index. Fish density is predictable based on the catch record and the effort of a catch series. This method is applied to predict fish population in order to find an exact number of individual in one area unit (Kasmiet al., 2012).

Optimum effort $\left(\mathrm{E}_{\mathrm{opt}}\right)$ is calculated by FOX model. The necessary equation for this model (Kasmi et al., 2012) is:

Relationship between CPUE and catch effort (E):

$$
\begin{gathered}
\text { Ln CPUE }=a+b E \\
c=E * e^{a-b E}
\end{gathered}
$$

\subsubsection{Trends Predictions Offer}

Prediction of the supply and demand of angel fish is done using the Least Squares Method (Yudiaroso, 2009), In general, the linear equation of time series analysis is : $Y=a+b X$.

Description: Y: variable sought trends

$\mathrm{X}$ : variable time (years)

To find the value of the constants a and $b$ parameters obtained by the formula: 


$$
\begin{gathered}
\mathrm{a}=\frac{(\Sigma \mathrm{Y})\left(\Sigma x^{2}\right)-(\Sigma \mathrm{X})(\Sigma \mathrm{Xy})}{\mathrm{n \Sigma X} 2-(\Sigma \mathrm{X})^{2}} \\
\mathrm{~b}=\frac{n \Sigma \mathrm{Xy}-\Sigma \mathrm{X} \Sigma \mathrm{y}}{\mathrm{n \Sigma x^{2 }}-(\Sigma \mathrm{X})^{2}}
\end{gathered}
$$

\section{Research Findings and Discussion}

\subsection{Exploitation Status}

The production of blue-girdled angelfish in South Sulawesi water is reducing over the years. According to the data from AKKIS (2015), the caught fish in 2014 is dropping by $66 \%$ from past year, 2006 (Figure 2). Production depends on how hard the utilization effort made on the target production. The higher target production, the harder effort shall be made and intensified. In fishing industry, it does not always run well because of many influencing factors, in particular, such as the location where the fish lives, fishing fleet capability and oceanographic condition.

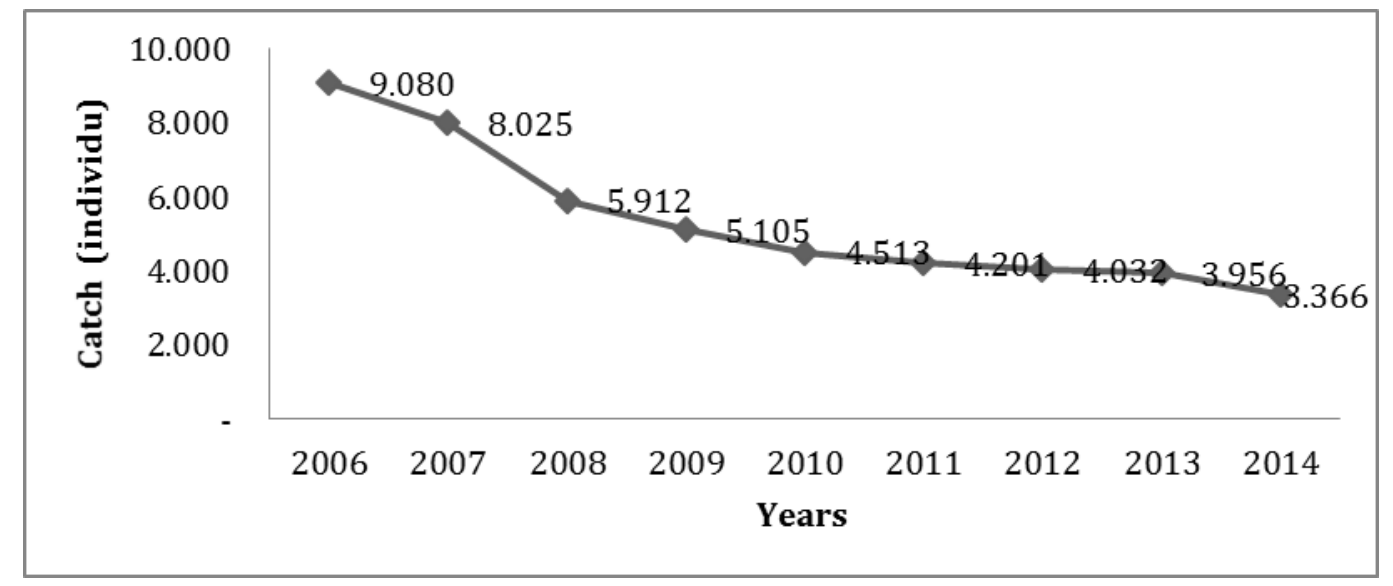

Figure 2. Time-based Trends of Fish Catch

Relationship between CPUE and catch effort (average number of fishermen per fishing boat is 15 people) (Figure 3) makes coefficient of determination $\left(R^{2}\right)$ 0.0132. Interaction between CPUE and catch effort posses weak relationship (under 0.7). . Correlation between CPUE and catch effort (f) indicates negative relationship based on the equation below: CPUE = 42,116-0.0793 f. It indicates that the more frequent catch effort (f), the weaker fishing gear productivity will be. Every catch effort addition by $f$ unit will reduce CPUE by multiplying 0.0793 fishes and $\mathrm{f}$ unit. Based on this calculation, it reflects the needs of controlled catch effort for the sake of sustainable fishery resource. It confirms Kasmi findings in 2012 that the value of relationship is regarded as high if the coefficient of correlation between CPUE and catch effort ranges from 0.7 to 0.9 . 


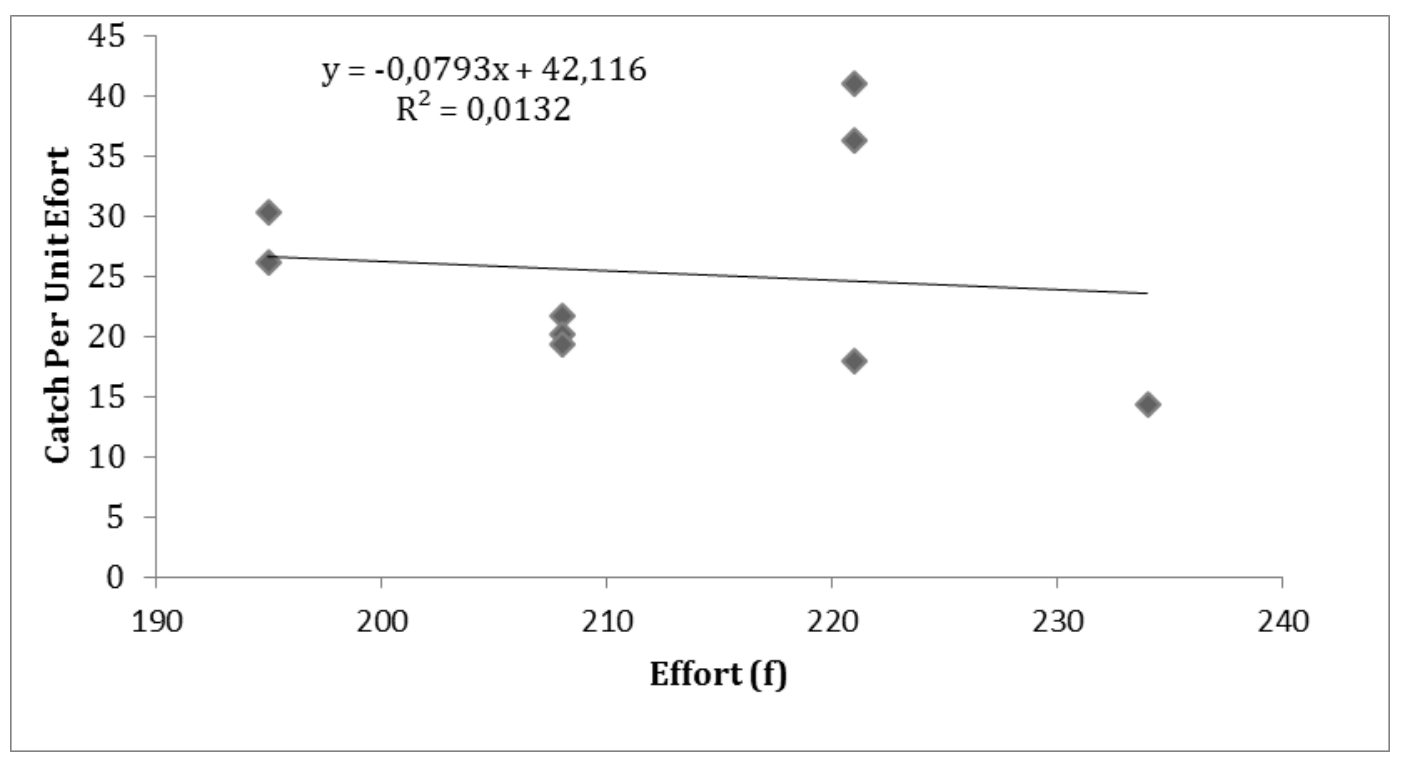

Figure 3. CPUE relates to the catch effort

Figure 4 points out a fact that even if the catch effort is increased, the amount of caught fish keeps decreasing. Apparently, it relates to a condition where the target catch area is selected. This blue-girgled angelfish catch status carried out during the catch period seems far above optimum level or above MSY, the increasing number of fishermant.. does not adds up the production, and conversely, the catch remains drop. This situation, thereby, is at the position as illustrated by $M S Y$ curve below. It supports what Fauzi (2006) had said that if there is no fishing activity (catch effort $=0$ ), production will be zero. If the effort remains to be elevated to point $\mathrm{E}_{\mathrm{MSY}}$, maximum production will be attained. Production level at this stage is called Maximum Sustainable Yield. Because of the quadratic curve of Yield-Effort, continuous effort exceeding point $\mathrm{E}_{\mathrm{MSY}}$ will not synchronized with production scale-up. At this condition, overfishing occurs.

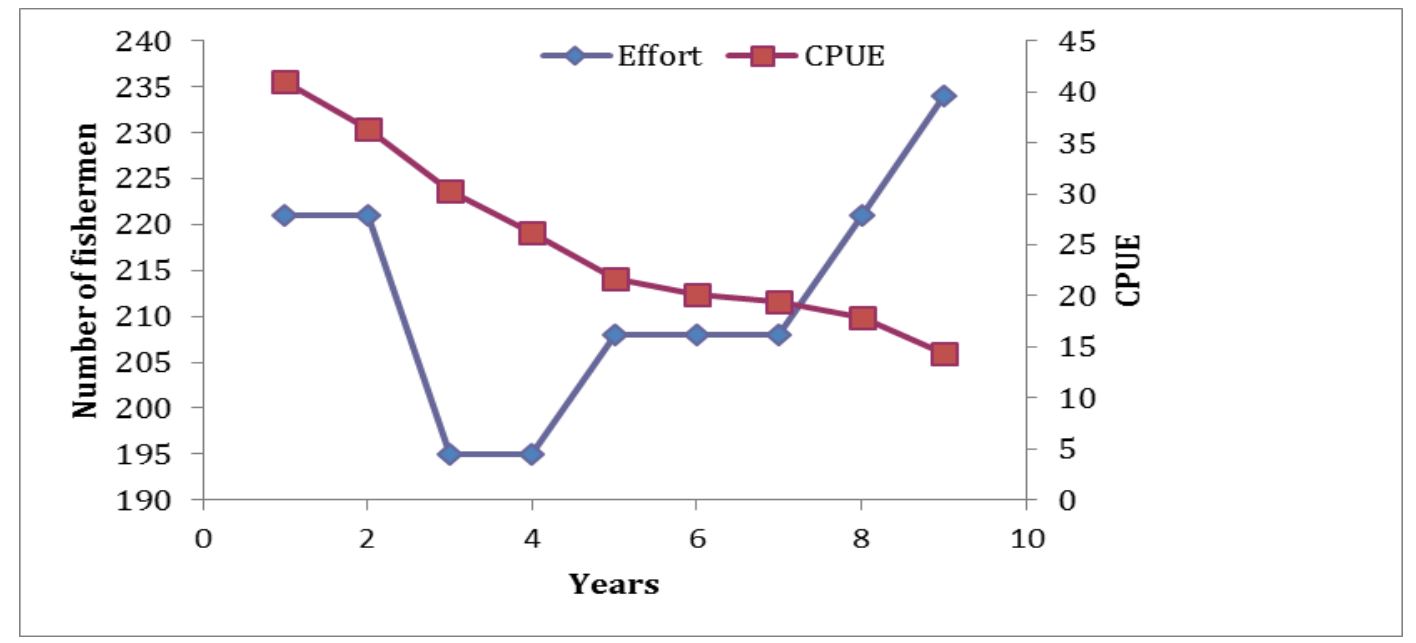

Figure 4. Total catch and fishing effort 2006-2014 


\section{Ml Macrothink}

The value of blue-girdled angelfish maximum sustainable yield (MSY) is 5,076 fish where the optimum effort $\left(f_{\text {opt. }}\right)=12$ fishing boats (Figure 5 ).

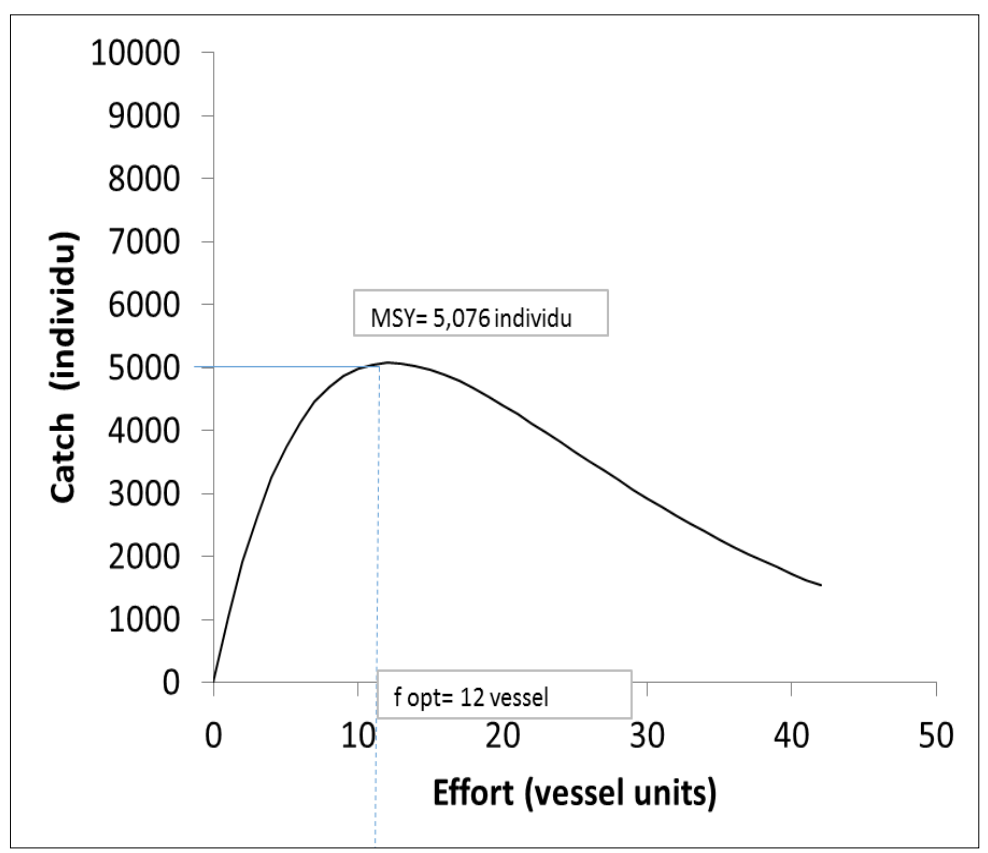

Figure 5. Fox yield-effort curve model

\subsection{Blue-girdled Angelfish Demand and Supply}

Blue-girdled angelfish demand collected from the field is unconfirmed.-There is a report abroad in South Sulawesi that at any fish caught by the fisherman, this angelfish will be completely sold out. According to Kasmi et al. (2010), Kasmi (2012, 2013), Kasmi \& Sulkifli (2013), the most appealing ornamental fish in global market is blue-girdled angelfish among others. At any fish caught, it is sold out without delay, so does the other ornamental fishes on which the exporters are focusing their attention. These fishes, however, are only found in particular fishing area that they are rarely available in ornamental fish breeding station.

When the price of blue-girdled angelfish tends to increase (Figure 6), according to the law of demand, this angelfish demand should be turning down. Since this ornamental fish falls under unique commodity, the law of demand does not apply. The exception on the law of demand occurs when a low supply provided in the marketplace causes a high demand from the consumer and price tends to increase.

Based on the law of supply, the higher price of goods and service, the greater supply of goods and service offered by the producer will be. In reality, however, such law of supply does not apply to ornamental fish export rate and price. Price of fish goes up, while the supply tends to goes down (Figure 6). It confirms statement of Fauzi (2006) that in principle, this Copes model reflects a balance between demand side and supply side in fishery commodity.

This demand depends on backward bending supply curve of fish on the fishery production rate at optimum level. Sometimes, there is a supply curve that is negatively inclined. It 
frequently occurs when the supply curve of fishery commodity bends backward because the population of wild fish is decreasing (Kasmi, 2012; 2013). It refers to the supply curve of fish based on Copes model from which this condition begins when the production of blue-girdled angelfish was initially raising and then dropping over and over as the impact of high exploitation, even if there was conservation act. The graphic indicates that the supply moves anticlockwise for in other word -the sharpening inclination of curve is caused by decreasing fish stock.

According to the historical data (Figure 6), it indicates that the supply and production of fish in Pangkajene Islands and Taka Bonerate Islands keeps descending, while the price keeps moving higher. In 2006, the supply of fish is 8,880 fishes and is IDR150,000 per fish. This supply drops to 3,166 fishes in 2010, but it is more expensive to IDR 210,000 (AKKII \& AKIS, 2014).

The phenomenon of the angelfish supply confirms the findings of Kasmi (2012) stating that equilibrium supply function is very simple from one fish stock where the access is open and comes after the fish stock provided by nature and the catch, i.e. growth equals with catch. Moreover, supply function will go up to Maximum Sustainable Yield and go down to zero point if the price keeps going higher. Therefore, supply function will finally makes supply dropped (Chopes, 1970, Kasmi, 2012). It is confirmed by Clark study (1990) that the curve in regulated open-access and regulated limited access following backward-bending supply function for small-sized fishing company and supply function is against demand function for one fish product as conventional commodity.

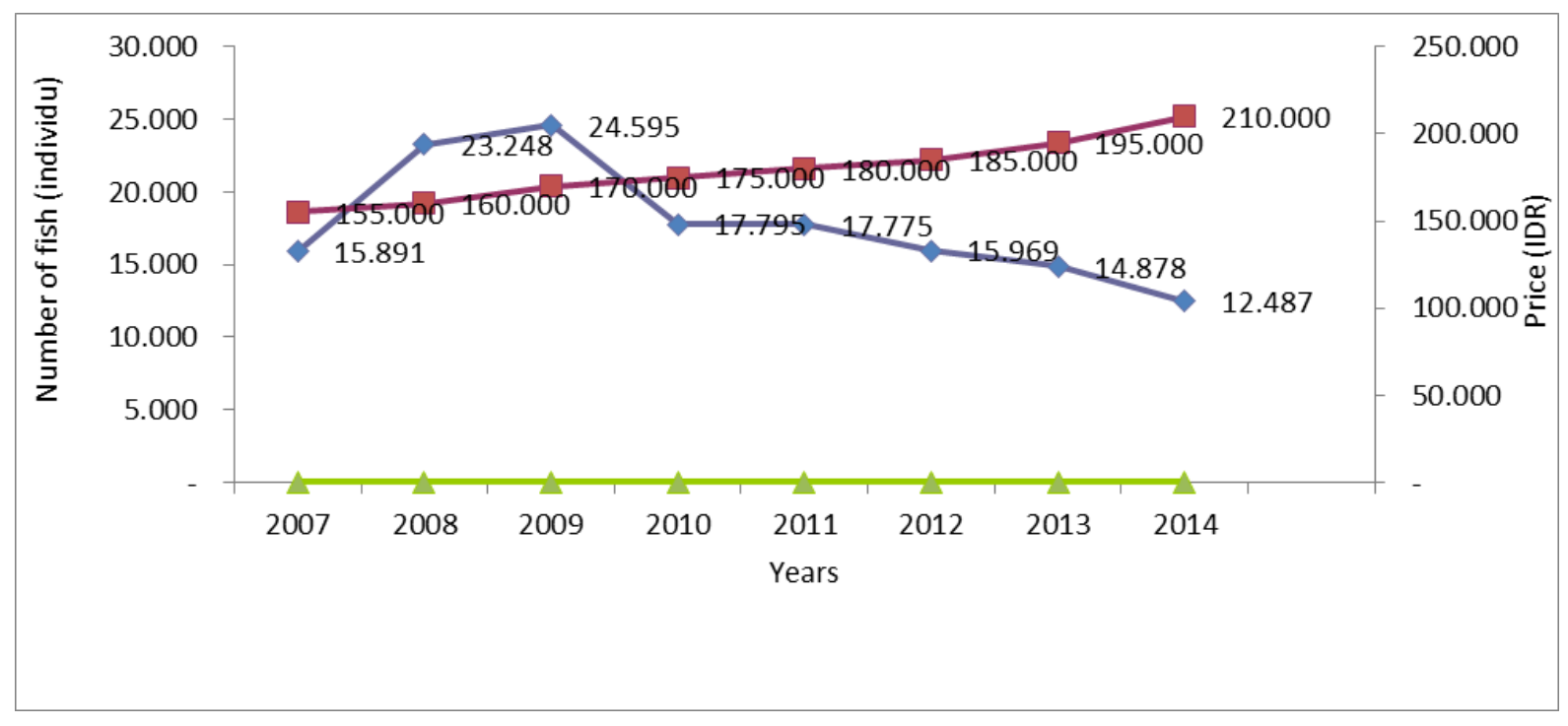

Figure 6. Angelfish supply curve in Indonesia, 2007-2014

Resource: AKKII and AKIS 2015 (unpublished, modified)

Based on blue-girdled angelfish sales data in Indonesia in 2007-2014 (Figure 6), it indicates that blue-girdled angelfish supply or catch traded in marketplace have reached 15,891 fishes, to 23,248 fishes, and fallen down to 17,795 fishes and in 2014, the sales data recorded only 12,487 fishes. This count reduction is collected from AKKII and AKIS year 2014. It is not 
caused by declining demand of consumer, but a downsizing of angelfish number in wild life. The biggest demand of blue-girdled angelfish comes from European Union whose the capability of purchasing up to 50\% of Indonesian total export of angelfish. Angelfish demand also comes from US by $40 \%$ and $10 \%$ of the demand comes Asian countries (Japan, Hong Kong and Korea).

Based on the data, it indicates that angelfish supply or production in Indonesia water, in general, keeps reducing and the price goes up significantly.

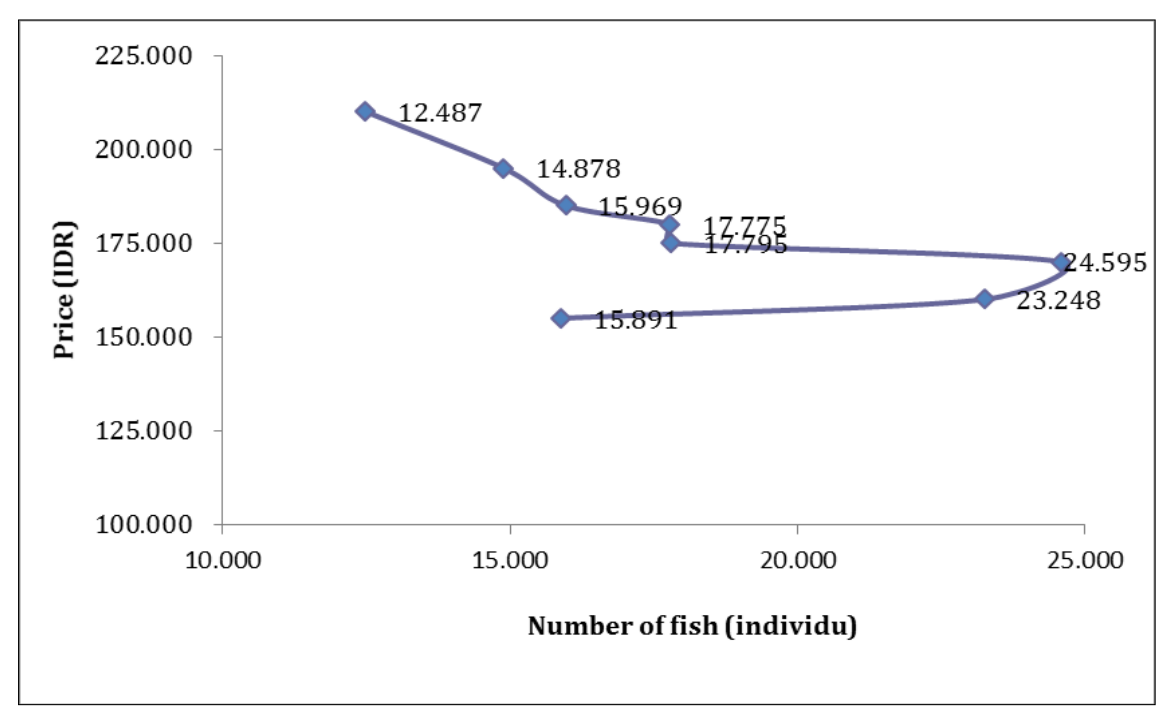

Figure 7. Negative-backward bending supply curve of angelfish in Indonesia 2007-2014

Resource: AKKII and AKIS 2015 (unpublished, modified)

Angelfish excess demand as well as its high price compared to the other ornamental fish may encourage the increase of fisherman activity to continually go fishing for blue-girdled angelfish. High interest to this ornamental fish is also proved when it is made as bargaining power when a new supplier wants to get involved in ornamental fish sale and purchase (Kasmi, 2012, 2013; Kasmi \& Sulkifli, 2013). Eventually, it will have impact on the angelfish population decline because of high exploitation. It causes negative slope on the supply curve (Figure 7). There was, initially, an increase of supply, but then decrease of supply occurs over and over.

This analysis is used to make a supply prediction of blue-girdled angelfish for five years ahead. By using historical data of supply from 2015 to ?, the supply prediction of blue-girdled angelfish for five years ahead will be predictable (Table 2).

Table 2. Supply prediction of Angelfish 2015-2019

\begin{tabular}{cc}
\hline Years & Supply (Individu ) \\
\hline 2015 & 3.756 \\
2016 & 3.166 \\
2017 & 3.035 \\
2018 & 1.844 \\
2019 & 662 \\
\hline
\end{tabular}


In 2015, blue-girdled angelfish supply was 3,756 fishes and would be 662 fishes only in 2016 . The supply prediction of angelfish will continually drop on the assumption that all variables that influence the blue-girdled angelfish for five years ahead are going to be same as the previous years.

\section{Conclusion And Suggestion}

The study indicates that the exploitation status of blue-girdled angelfish in South Sulawesi water is far above the maximum sustainable yield (MSY). Therefore, the more catch effort will reduce the productivity of fishing gear. It indicates that angelfish faces overfishing. Moreover, the backward bending supply curve indicates that the supply is going down, even if the price goes up as the impact of decreasing fish stock.

\section{Assistance}

This study activity is a part of Fundamental study entitled "Sustainable Management Strategy for Blue-girdled Angelfish (Pomacanthus navarthus) in South Sulawesi Water"'funded by DIKTI budget year 2015. This study success is inseparable from the support of various parties. Our gratitude for the Sulawesi Coral and Ornamental Fish Association (AKIS), the Indonesia Coral, Shell and Ornamental Fish Association (AKKII) and all institutions in associated and the whole research team for the success of study.

\section{References}

AKKII dan AKIS. (2014). Laporan Realisasi Produksi Ikan Hias di Perairan Sulawesi Selatan, Jakarta.

Balai Riset Perikanan Laut. (2006). Ikan Hias Laut Indonesia. Penebar Swadaya, Jakarta.

Charles, A. T. (2001). Toward Sustainability. The Fishery Experience Ecological Economics, 11, 201 - 211. https://doi.org/10.1016/0921-8009(94)90201-1

Clark, C. (1990). Mathematical bioeconomics, the optimal management of renewable resources. 2nd ed. New York: Wiley.

Copes, P. (1970). The backward-bending supply curve of the fishing industry. Scottish Journal of Political Economy, 17, 69-77.

https://doi.org/10.1111/j.1467-9485.1970.tb00487.x

FAO. (1995). Introduksi Pengkajian Stok Ikan Tropis. Kerjasama dengan Organisasi Pangan dan Pertanian Perserikatan Bangsa-Bangsa, Pusat Penelitian dan Pengembangan Perikanan, Badan Penelitian dan Pengembangan Pertanian, Jakarta.

Fauzi, A. (2006). Ekonomi Sumberdaya Alam dan Lingkungan, Teori dan aplikasi. Gramedia Pustaka Utama, Jakarta.

Indra. (2007). Model Bio-Ekonomi Opsi Rehabilitasi Sumberdaya Perikanan di Provinsi Nangroe Aceh Darussalam. Disertasi. IPB, Bogor.

Kasmi, M., Netsa Natsir., Jompa. J dan Budimawan. (2014). Struktur Ukuran, Pertumbuhan dan Rasio Seksual Ikan Hias Injel Napoleon (Pomachantus xanthometopon) di Perairan Sulawesi Selatan. Jurnal Oseanologi dan Limnologi di Indonesia (OLDI), 40(3): 283 - 294. 


\section{Macrothink}

Journal of Agricultural Studies ISSN 2166-0379 2017, Vol. 5, No. 1

Kasmi, M dan Sulkifli., (2013). Hubungan Karakteristik Habitat dengan Kelimpahan Ikan Hias Injel Napoleon (Pomacanthus xanthometopon) di Perairan Kabupaten Pangkep, Sulawesi Selatan. Jurnal Karya Ilmiah Agrokompleks (Galung Tropika), 2(3), 123 - 128.

Kasmi, M. (2013). Faktor-Faktor yang Mempengaruhi Permintaan dan Penawaran Ekspor Ikan Hias Injel Napoleon Pomacanthus xanthometopon di Sulawesi Selatan. Jurnal Ilmiah Agrokompleks (Galung Tropika), 2(3).

Kasmi, M dan Sulkifli., (2013). Analisis Ekspor Ikan Hias Injel Napoleon (Pomacanthus xanthometopon) di Sulawesi Selatan. Jurnal Karya Ilmiah Bumi Kita (Lingkungan Hidup dan Pengelolaan Sumberdaya Alam), 2(11), 79 - 94.

Kasmi, M. (2012). Bio-ekologi dan Status Pemanfaatan Ikan Hias Injel Napoleon (Pomacanthus xanthometopon) di Perairan Sulawesi Selatan. Disertasi. UNHAS, Makassar. $126 \mathrm{hlm}$.

Kasmi, M., Nessa Natsir., Jompa. J dan Budimawan. (2011). Hubungan Kondisi Habitat dengan Kelimpahan Ikan Hias Injel Napoleon (Pomacanthus xanthometopon) di Perairan Sulawesi Selatan. Jurnal Sosial Ekonomi Kelautan dan Perikanan (Ponggawa), 6(2), 67-78.

Kasmi, M., Netsa Natsir., Jompa. J dan Budimawan. (2011). Studi Pendahuluan Tentang Kelimpahan Ikan Hias Injel Napoleon (Pomacanthus xanthometopon) di Perairan Kabupaten Pangkep, Sulawesi Selatan. Dalam: Nugraheni, S. P., Istiqomah, I dan Ghozali, N.F (Eds). Prosiding Seminar Nasional Tahunan VIII Hasil Penelitian Perikanan dan Kaelautan Tahun 2011 Jilid II: Manajemen Sumberdaya Perikanan, Jurusan Perikanan dan Kelautan Fakultas Pertanian, Universitas Gajah Mada, 16 Juli 2011, Yogyakarta:KL-04(1-5).

Kasmi, M., Yanuarita, D., Jompa, J., Nessa, N. M., Budimawan., Buhari, N, \& Husain, A. A. (2010). Trends and Mangement Challenges of Ornamental Reef Fishes Trading in South Sulawesi. Presented at International Symposium on Small Islands and Coral Reef in Ambon, August 4-5, 2010.

Yudiarosa, I. (2009). Analisis Ekspor Ikan Tuna Indonesia. Magister Ilmu Ekonomi Pertanian. PPSUB. Jurnal WACANA Vol. 12 No. 1 Januari 2009. ISSN. 14110199

\section{Copyright Disclaimer}

Copyright for this article is retained by the author(s), with first publication rights granted to the journal.

This is an open-access article distributed under the terms and conditions of the Creative Commons Attribution license (http://creativecommons.org/licenses/by/4.0/). 